\title{
ELITE DAN INTEGRASI SOSIAL DALAM MASYARAKAT PAGERSARI, MUNGKID, MAGELANG 1967-1988
}

\section{Tri Karyanti}

\author{
Universitas AKI Semarang
}

Alamat korespondensi: tri.karyanti@unaki.ac.id

Diterima/ Received: 11 Januari 2018; Disetujui/ Accepted: 30 Maret 2018

\begin{abstract}
This study examines the significant role of local elites in the efforts of social integration in Pagersari, Mungkid, Magelang. Social integration is the cooperation of all society members, ranging from individuals, families, and society, so it can generate unity and diversity in the form of shared values. In the realization of social integration, it required leaders who were able to integrate all kind of conflicts in society. After 30 September 1965 event until the reign of the New Order in Pagersari, there were various internal conflicts among people who were motivated by various problems such as political differences, religious and family internal affairs. It is known that the active role of local leaders or elites has especially become an important factor to solve these conflicts. It even able to encourage the realization of social integration in Pagersari. To handle conflicts, it was solved by finding the core problems, then trying to resolve until accepted by the conflict's parties. Some of the media for integration by a good leadership, religious and cultural approach.
\end{abstract}

Keywords: Elite; Conflict; Social Integration.

\begin{abstract}
Abstrak
Melalui metode sejarah artikel ini mengkaji signifikansi peranan elite lokal dalam upaya integrasi sosial di Desa Pagersari, Kecamatan Mungkid, Kabupaten Magelang, Jawa Tengah. Integrasi sosial merupakan kerja sama dari seluruh anggota masyarakat, mulai dari individu, keluarga, dan masyarakat secara keseluruhan, sehingga menghasilkan persatuan dan kesatuan yang berupa nilai-nilai yang dijunjung bersama. Dalam mewujudkan integrasi sosial dibutuhkan pemimpin yang mampu menyatukan segala macam pertentangan atau konflik dalam masyarakat. Pascaperistiwa Gerakan 30 September 1965 hingga memasuki masa pemerintahan Orde Baru, di Desa Pagersari terjadi berbagai konflik internal antarwarga yang dilatarbelakangi oleh beragam permasalahan seperti perbedaan paham politik, keagamaan dan permasalahan internal keluarga. Melalui artikel ini diketahui bahwa peranan aktif pemimpin atau elite lokal terutama telah menjadi suatu faktor penting dalam menyelesaikan berbagai konflik tersebut, bahkan mampu mendorong terwujudnya integrasi sosial di Desa Pagersari. Penanganan konflik menuju masyarakat yang terintegrasi ditempuh dengan mencari sumber permasalahannya, kemudian berusaha menyelesaikannya hingga bisa diterima oleh pihak-pihak yang terlibat konflik. Beberapa sarana yang digunakan untuk mewujudkan integrasi masyarakat Desa Pagersari antara lain melalui keteladanan dan kepemimpinan yang baik, pendekatan agama dan budaya.
\end{abstract}

Kata Kunci: Elite; Konflik; Integrasi Sosial. 


\section{PENDAHULUAN}

Integrasi sosial senantiasa menjadi isu penting bagi sebuah bangsa, termasuk Indonesia. Terlebih pasca-peristiwa Gerakan 30 September (G30S) 1965 hingga memasuki masa transisi pemerintahan Orde Lama ke Orde Baru, pemerintah berupaya keras untuk menciptakan stabilitas nasional. Desa Pagersari merupakan salah satu desa di Kecamatan Mungkid, Kabupaten Magelang, Provinsi Jawa Tengah dengan tingkat konflik sosial yang cukup tinggi. Berbagai konflik yang terjadi di desa tersebut memiliki akar permasalahan yang beragam, antara lain konflik berlatar belakang permasalahan politik, konflik berlatar belakang permasalahan keluarga, dan konflik berlatar belakang perbedaan paham keagamaan.

Pasca-peristiwa G30S, Desa Pagersari tercatat sebagai salah satu desa yang sebagian penduduknya terlibat dalam organisasi terlarang Partai Komunis Indonesia (PKI). Hal tersebut menjadi salah satu sumber konflik yang sangat serius di daerah itu, terlebih setelah dikeluarkannya Ketetapan Majelis Permusyawaratan Rakyat Sementara No. XXV/MPRS/1966, tentang pembubaran PKI sebagai organisasi terlarang di seluruh wilayah Indonesia. ${ }^{1}$ Hal tersebut berimplikasi pada terjadinya kekacauan di berbagai daerah akibat penangkapan dan dilakukannya tindak kekerasan pada para simpatisan/pengikut PKI. Kondisi semacam itu juga terjadi di Desa Pagersari.

Terkait dengan konflik berlatar belakang permasalahan keluarga, di setiap desa biasanya terdapat keluarga-keluarga yang memiliki pengaruh kuat dalam masyarakat. Mereka terdiri dari golongan bendara dan priyayi yang sangat dihormati oleh masyarakat (Koentjaraningrat, 2002: 344). Di Desa Pagersari terdapat keluargakeluarga semacam itu yang sangat disegani dan memiliki pengaruh kuat di masyarakat. Mereka hidup berdampingan satu sama lain dan biasanya memiliki harta keluarga yang lebih banyak dari penduduk desa pada umumnya. Namun demikian, pada bagian yang terakhir ini tampaknya justru sering kali menjadi sumber konflik antarpihak-pihak internal dalam keluarga tersebut. Secara khusus, sumber konflik antarindividu yang masih mempunyai hubungan kekerabatan itu sering terjadi karena masalah harta warisan. Konflik internal tersebut biasanya sampai harus melibatkan bantuan pihak-pihak luar untuk mengatasinya.

Sebagaimana masyarakat pedesaan di Jawa Tengah, masyarakat Pagersari dalam aspek keagamaan mayoritas merupakan penganut agama Islam. Akan tetapi, dalam pemahaman dan pelaksanaan ajaran-ajarannya antara kelompok masyarakat satu dan yang lain mempunyai corak yang berbeda. Kelompok Islam santri di Desa Pagersari misalnya terbagi menjadi dua, yaitu kelompok pengikut organisasi Islam Nahdhatul Ulama (NU) dan pengikut organisasi Islam Muhamadiyah. Selain itu terdapat pula penganut ajaran Islam sinkretik atau yang disebut Kejawen ${ }^{2}$ dan penganut agama lain seperti Kristen dan Katholik. Keragamanan keyakinan ini memiliki potensi konflik yang besar. Mereka semua hidup berdampingan satu sama lain, tetapi biasanya memiliki hubungan yang cenderung tidak dekat, bahkan kadangkadang diwarnai ketegangan atau permusuhan. Ketegangan terutama sering terjadi di antara pengikut NU dan Muhammadiyah. NU dan Muhammadiyah sebenarnya merupakan dua organisasi yang mewakili dua golongan besar umat Islam di Indonesia yang beraliran tradisional dan modernis. Dalam pandangan NU, disebutkan bahwa jika seorang muslim ingin menjalankan ajaran agama Islam dalam kehidupan, ia harus berpedoman kepada penafsiran-penafsiran yang diberikan oleh salah satu dari empat Imam mazhab (Hanafi, Maliki, Syafii dan Hanbali) sebagai satu-satunya pedoman (Ma'arif, 1985: 57). Sementara itu, di lain pihak Muhammadiyah ingin menghidupkan kembali semangat ijtihad dalam menelusuri dan mencari ajaran Islam sejati di tengah-tengah tradisi yang telah tua.

Masyarakat dengan berbagai potensi konflik sangat rentan berujung pada pertentangan terbuka yang dapat memakan banyak korban jiwa. Akan tetapi, di Desa Pagersari hal demikian itu dapat dihindari. Penanganan terhadap berbagai potensi konflik (laten) semacam itu telah berhasil dilakukan melalui berbagai pendekatan. Peranan pemimpin 
sangat penting guna menciptakan kondisi yang kondusif. Namun demikian, pemimpin tersebut harus bisa diterima oleh semua golongan masyarakat. Dalam kasus Desa Pagersari, di bawah kepemimpinan Wardoyo sebagai kepala desa sejak masa transisi dari Orde Lama hingga memasuki masa Orde Baru, potensi konflik berhasil ditangani, bahkan dilakukan berbagai upaya integrasi sosial masyarakat melalui berbagai pendekatan. Bagaimana gambaran konflik sosial di Desa Pagersari dan upaya Wardono sebagai elite lokal bersama masyarakat setempat dalam mencapai stabilitas dan integrasi sosial pascaperistiwa G30S hingga memasuki masa pemerintahan Orde Baru, ingin diuraikan lebih jauh dalam artikel ini. Sebagaimana diketahui desa tersebut memiliki latar belakang struktur sosial yang cukup kompleks, sehingga penelitian ini menjadi unik untuk dikaji.

Guna membantu menjelaskan berbagai fenomena sejarah dalam kajian ini, maka digunakan beberapa konsep sosiologi. Permasalahan peranan elite lokal dalam meredam dan menangani konflik hingga terjadinya upaya intergasi sosial menjadi fokus penelitian ini. Dahrendorf, seperti dikutip oleh Burke, menyatakan bahwa sebagai salah satu konsep sosiologi sentral, 'peranan sosial' didefinisikan sebagai pola-pola atau normanorma perilaku yang diharapkan dari orangorang yang menduduki suatu posisi tertentu dalam struktur sosial (Burke, 1992: 47). Sementara itu elite lokal adalah individu yang memegang peranan penting dalam keputusankeputusan politik pada tingkat lokal. Keller berpendapat bahwa konsep mengenai elite menunjuk kepada suatu minoritas pribadipribadi yang diangkat untuk melayani suatu kolektivitas dengan cara yang bernilai sosial. Elite sebagai minoritas bersifat sangat efektif dan bertanggung jawab terhadap orang lain, tempat golongan elite itu memberikan tanggapannya (Keller 1995:28). Oleh karena itu, peranan elite lokal dalam kajian ini adalah kewenangan dalam mengatur seseorang atau suatu kelompok masyarakat, yang pada batas-batas tertentu dapat meramalkan perbuatan orang lain, sehingga dengan demikian orang yang bersangkutan dapat menyesuaikan perilaku sendiri dengan perilaku orang lain sekitarnya. Pemimpin atau elite lokal dalam hal tersebut juga berwenang dan berperan dalam menangani konflik dan mendorong terjadinya dintegrasi sosial di masyarakat. Konflik sendiri adalah proses pencapaian tujuan dengan cara melemahkan pihak lawan, tanpa memperhatikan norma dan nilai yang berlaku. Pribadi atau kelompok yang menyadari adanya perbedaan misalnya dalam ciri-ciri fisik, emosi, unsur-unsur budaya, pola-pola perilaku, dan seterusnya dengan pihak lain dapat mempertajam perbedaan yang ada, sehingga menjadi suatu pertentangan atau pertikaian/ konflik (Wijono, 1993: 37-41). Oleh karena itu, berbagai pendekatan dilakukan untuk meredam konflik dan mendorong ke arah terjadinya integrasi sosial. Integrasi sosial dapat terwujud sebagai kerja sama dari seluruh anggota masyarakat, mulai dari individu, keluarga, dan masyarakat secara keseluruhan sehingga menghasilkan persatuan-persatuan berupa konsensus nilai-nilai yang dijunjung tinggi bersama (Maran, 2001: 184-185).

\section{METODE}

Kajian ini dilakukan dengan menggunakan metode sejarah, yaitu seperangkat prinsipprinsip sistematis untuk mencari dan memanfaatkan sumber-sumber sejarah. Metode sejarah adalah proses menguji dan menganalisis secara kritis rekaman dan peninggalan masa lampau. Dengan metode sejarah dapat direkonstruksi sebanyak-banyaknya peristiwa masa lampau manusia. Metode sejarah terdiri dari empat tahap, yakni heuristik, kritik, interpretasi, dan historiografi (Gottschalk, 1983: 18 dan 32).

Kajian ini menggunakan sumber-sumber yang diperoleh melalui studi dokumen dan metode sejarah lisan. Melalui studi dokumen, didapatkan sumber-sumber tertulis berupa catatan dan arsip-arsip pribadi koleksi Wardono sebagai salah seorang subyek dalam kajian ini. Selain itu, diperoleh pula arsip-arsip milik Kantor Desa Pagersari yang terkait dengan keterlibatan beberapa warga yang terlibat dalam Organisasi Terlarang PKI. Sumber tertulis lain yang digunakan adalah hasil tulisan atau berita- 
berita sezaman yang berhubungan dengan peristiwa yang dibahas, yang telah dimuat di koran-koran lokal. Penulis dalam hal tersebut antara lain melakukan studi dokumen di Arsip Daerah Kabupaten Magelang, Perpustakaan Suara Merdeka, Perpustakaan Monumen Pers dan Perpustakaan Daerah Jawa Tengah.

Metode sejarah lisan adalah seperangkat aturan pengumpulan data dan informasi guna penulisan sejarah yang dilakukan melalui wawancara peristiwa sejarah. Wawancara sejarah lisan dilakukan dengan Wardono (70 tahun), mantan Kepala Desa Pagersari yang menjabat dari 1967 sampai 1988. Informasi yang didapatkan dari narasumber tersebut berkisar pada konflik antardusun di wilayah Desa Pagersari selama ia menjabat kepala desa, bagaimana usaha mengintegrasikan kehidupan masyarakat beragam latar belakang, dan bagaimana merangkul orang-orang eks PKI yang tinggal di desa tersebut. Pelaku sejarah selanjutnya adalah Sugito, pensiunan penilik Sekolah Dasar (SD) (72 tahun). Pada masa kepemimpinan Wardono, ia menjabat sebagai Ketua Lembaga Ketahanan Masyarakat Desa (LKMD). Informasi lisan juga didapatkan dari Mami Sukami (72 tahun), seorang mantan kepala Sekolah Dasar Negeri Pagersari (19821998); dari beberapa informan lain seperti Riyadi (60 tahun), tokoh agama; Sukisyanto (65 tahun), mantan sekretaris Desa Pagersari; Mudakir (45 tahun), perangkat desa; Sunyoto (70 tahun), mantan Kasi Urusan Kesejahteraan Desa Pagersari; Sugati (70 tahun), seorang petani; serta beberapa narasumber yang lain. ${ }^{3}$ Pelaku-pelaku sejarah tersebut semuanya adalah warga Desa Pagersari yang menyaksikan bahkan di antaranya adalah pelaku sejarah yang terjadi di Desa Pagersari pada 1967-1988.

\section{KONFLIK SOSIAL DI DESA PAGERSARI}

\section{Konflik Politik Pasca-Peristiwa G30S 1965 dan Terpilihnya Wardono sebagai Kepala Desa Pagersari}

Wardono yang lahir pada 29 Juni 1941 merupakan seorang putra seorang kepala desa bernama Kromodidjojo. Wardono tumbuh di lingkungan Islami. Dusun Pagerjurang, tempat tinggal keluarga Wardono merupakan kampung yang mayoritas penduduknya dikenal sebagai pengikut organisasi Islam Muhammadiyah. Meskipun demikian, Wardono berpengalaman mendapatkan pendidikan di sekolah-sekolah non-Islam. Ia pernah bersekolah di Sekolah Dasar (SD) di Kanisus Kamal, Desa Pagersari, Sekolah Menengah Pertama Negeri (SMPN) Muntilan (sekarang SMPN I), dan Sekolah Menengah Atas (SMA) Santo Thomas, Yogyakarta. Wardono sempat melanjutkan pendidikan di Fakultas Ekonomi Universitas Indonesia pada 1962, namun tidak sampai lulus sarjana karena pada tahun berikutnya ia diterima bekerja sebagai pegawai negeri sipil di Direktorat Kepenjaraan Departemen Kehakiman. Baru satu tahun bekerja, Wardono mendapat tugas belajar di Akademi Ilmu Pemasyarakatan (AKIP) (Wawancara dengan Wardono, 29 Juni 2011).

Meskipun telah memiliki pekerjaan yang mapan di Jakarta, Wardono memiliki keinginan besar untuk kembali ke kampung halamannya. Oleh karena itu, ketika mendengar berita tentang rencana penyelenggaraan pemilihan kepala desa di Desa Pagersari, Wardono terdorong untuk ikut serta. Partisipasi Wardono dalam pemilihan kepala desa Pagersari pada dasarnya merupakan permintaan dari orang tua dan keluarganya. Bagi Wardono, keputusan untuk ikut serta dalam pemilihan kepala desa di Pagersari merupakan pilihan yang sulit karena baginya masa depan di Jakarta dengan pekerjaan sebagai pegawai negeri sudah jelas apalagi ditambah dengan tugas belajar yang sedang dijalaninya. Menjelang akhir masa tugas belajar di AKIP, Wardono memutuskan untuk kembali ke desa dan mencalonkan diri sebagai kepala desa. Sebagai konsekuensi dari tindakannya tersebut Wardono diberhentikan dengan hormat sebagai Pegawai Negeri Sipil di Kantor Direktorat Kepenjaraan Departemen Kehakiman, dengan pertimbangan bahwa tindakannya itu juga bertujuan untuk memberikan pelayanan di masyarakat (Wawancara dengan Wardono, 29 Juni 2011). Ia secara otomatis diberhentikan pula dari AKIP (Arsip Pribadi Wardono, Surat Pemberhentian Tugas Beladjar). 
Pada saat peristiwa G30S tahun 1965 terjadi, Desa Pagersari dipimpin oleh seorang kepala desa bernama Akhadi. Namun, Akhadi kemudian diberhentikan karena dituduh terlibat dalam keanggotaan PKI terkait kedudukannya sebagai salah satu Pengurus PKI Kabupaten Magelang. Setelah itu tugas kepala desa sementara dibebankan kepada carik Desa Pagersari bernama Marsono, seorang pengikut Partai Nasional Indonesia (PNI) (Wawancara dengan Sugito, 20 November 2011).

Setelah ketetapan MPRS No. XXV/ MPRS/1966 yang menyatakan bahwa ideologi PKI tidak lagi diizinkan hidup di Indonesia dikeluarkan, kemudian banyak terjadi pembantaian dan penangkapan terhadap anggotaanggota PKI. Sejarah mencatat bahwa dalam menumpas gerakan yang dianggap kontra revolusioner tersebut memunculkan tiga kekuatan utama yang sangat dominan dan berusaha sekuat tenaga menumpas PKI (Karim, 1983: 153). Ketiga kekuatan tersebut adalah kalangan Islam, tentara, dan angkatan muda yang terdiri dari pelajar dan mahasiswa yang selanjutnya disebut angkatan 66. Kalangan Islam menjadi kekuatan politik utama, karena PKI sebelum kehancurannya lebih dikenal sebagai kelompok "antiagama" dan kelompok Islam menjadi sasaran PKI, karena Islam adalah kekuatan besar yang secara organisatoris waktu itu dipandang lemah namun disegani dalam mengembangkan pengaruh komunis di Indonesia (Karim, 1983: 154-157). Pada awal 1960-an umat Islam memang sangat tersisih, tidak mempunyai suara di gelanggang politik nasional. Dengan adanya gerakan menumpas PKI yang dipimpin oleh tentara, umat Islam merasa terpanggil. Kehancuran komunis berarti kehilangan musuh utama yang akan berdampak memberi angin segar bagi kalangan umat Islam dalam kehidupan politik di Indonesia. Oleh karena itu, seruan "ganyang PKI" pertama-tama disambut oleh umat Islam dengan begitu bersemangat. Dengan dukungan Tentara Nasional Indonesia (TNI) Angkatan Darat, umat Islam bersama kekuatan sosial yang lain berada di barisan depan dalam memberantas PKI di Indonesia. Di sisi lain terdapat pula keterlibatan mahasiswa dan pelajar yang tergabung dalam dua organisasi besar yaitu Kesatuan Aksi Mahasiswa Indonesia (KAMI) dan Kesatuan Aksi Pemuda dan Pelajar Indonesia (KAPPI).

Gerakan "ganyang PKI" ternyata juga menjalar sampai ke Desa Pagersari. Selain penangkapan terhadap kepala desa, Akhadi karena keterlibatannya dengan PKI, kemudian terjadi pula peristiwa pembakaran rumah-rumah penduduk di Dusun Jetis pada sekitar bulan Maret 1966. Sekelompok pemuda setelah shalat Jumat dari Masjid Sirojudin di belakang pabrik kertas PN Blabak berjalan berbondong-bondong menuju Dusun Jetis. Dusun Jetis dianggap sebagai wilayah para pengikut PKI di Desa Pagersari. Di Dusun Jetis kemudian beberapa rumah warga dibakar habis. Beberapa rumah yang dibakar antara lain adalah rumah-rumah milik warga setempat bernama Muhadi, Poniman, Suhono, dan Mangun. Selain membakar rumah, warga dari luar dusun tersebut juga merusak berbagai perabotan rumah, sehingga hampir tidak bersisa. Pascaperistiwa tersebut, mereka umumnya tinggal menumpang di rumah kerabat masingmasing, seperti Muhadi yang tinggal bersama orang tuanya sampai dua tahun hingga bisa membangun kembali rumah tinggalnya (Wawancara dengan Muhadi, 21 November 2011).

Peristiwa G30S 1965 membawa perubahan besar dalam kehidupan sosial politik masyarakat, dari tingkat nasional sampai ke wilayah pedesaan. Dalam Undang-Undang No. 10/1966 terkait persyaratan untuk menduduki jabatan politik atau publik hanya diperbolehkan bagi orang-orang yang tidak terlibat baik langsung, maupun tidak langsung dalam gerakan kontrarevolusi G30S/PKI dan atau organisasi terlarang/terbubar lainnya (Undang-Undang No. 10 tahun 1966 tentang Kedudukan MRPS dan DPRGR menjelang Pemilu, Bab VII Pasal 12 Tentang Syarat-Syarat Keanggotaan MPRS/DPRGR). Oleh karena itu, penunjukkan kepala desa pasca peristiwa G30S terutama mempertimbangkan "kebersihan" mereka dari keterlibatan sebagai anggota atau simpatisan dengan organisasi terlarang PKI. 
Pemilihan kepala Desa Pagersari kemudian dilaksanakan pada 8 Februari 1967. Pemilihan itu diikuti oleh tiga orang kontestan, yaitu Wardono, Suyud, dan Dimyati. Dari sebanyak 2024 orang penduduk Desa Pagersari, hanya sebanyak 1158 orang yang memiliki hak pilih. Desa Pagersari memiliki tujuh wilayah dusun, yaitu Dusun Pagerjurang, Tapen, Pongangan, Jetis, Kamal, Karanggawang, dan Tangulangin. Sebanyak 1158 hak pilih yang ada tersebar meliputi Dusun Pagerjurang 385 orang, Karanggawang 90 orang, Tanggulangin 160 orang, Kamal 236 orang, Tapen/Pongangan 273 orang, dan Jetis 171 orang.

Wardono berasal dari Dusun Pagerjurang yang mayoritas penduduknya merupakan pengikut Muhammadiyah. Dimyati, seorang tokoh NU berasal dari Dusun Tapen, sedangkan Suyud adalah seorang pegawai negeri berasal dari Dusun Kamal. Di antara tiga calon tersebut, Wardono mendapat dukungan paling kuat dari Muhammadiyah dan PNI, bahkan ada gerakan KAMI/KAPPI Kecamatan Mungkid yang dipimpin oleh Ambar yang siap bergerak melakukan demonstrasi jika Wardono tidak terpilih sebagai kepala desa. Pada saat itu ia dipandang sebagai seorang nasionalis yang dianggap jauh dari pengaruh dan keterlibatan dengan PKI. Dimyati yang berasal dari Dusun Tapen adalah seorang tokoh NU di Pagersari yang tentunya mendapat dukungan masyarakat NU di Pagersari. Suyud mendapat dukungan dari mantan kepala desa Akhadi yang sudah lengser dari jabatan sebagai kepala desa. Meskipun telah dihukum penjara, namun Akhadi masih mempunyai pendukung kuat, terutama dari warga Dusun Jetis, Pongangan, dan Kamal. Dukungan terhadap Suyud masih mengalir melalui keluarga dan orang-orang dekat Akhadi (Wawancara dengan Hj. Mami Sukami, 20 November 2011). Akan tetapi, dukungan itu tidak mutlak, karena masih terpecah dengan dukungan untuk Wardono.

Wardono pun akhirnya berhasil terpilih menjadi kepala Desa Pegersari pada 1967 berkat dukungan berbagai pihak (Arsip Pribadi Wardono, Berkas Pengabsjahan Pemilihan Kepala Desa Pagersari jang Diadakan pada Tanggal 8 Pebruari 1967). Selain itu, latar belakang kelurga Wardono juga menjadi salah satu modal penting dalam keikutsertaannya pada pemilihan kepala desa tersebut. Sesudah zaman penjajahan posisi kepala desa biasanya diduduki berkat keturunan, bahwa anak laki-laki pertama yang biasanya menggantikan jabatan kepala desa apabila ayahnya meninggal atau meletakkan jabatan (Koentjaraningrat, 1982: 200). Begitu juga dengan Wardono, almarhum ayahnya adalah mantan kepala desa, dengan demikian secara langsung sudah memiliki pengaruh sebagai tokoh yang dihormati dan disegani masyarakat. Perjalanan memimpin masyarakat sebagai kepala desa yang masyarakatnya berpotensi konflik tentu bukan persoalan mudah, namun berkat pengalaman pendidikannya di Akademi Ilmu Pemasyarakatan dan Pegawai Negeri di Departemen Kehakiman rupanya telah menjadi bekal penting dalam mengatasi berbagai konflik dan permasalahan di lingkungan desa yang dipimpinnya.

\section{Konflik Sosial Keagamaan}

Muhammadiyah dan NU adalah dua organisasi Islam terbesar di Indonesia. Umum diketahui bahwa kedua organisasi ini memiliki berbagai perbedaan pandangan dalam berbagai masalah furu' (cabang) pelaksanaan ibadah Islam. Muhammadiyah yang identik dengan pemikiran moderen misalnya membuka pintu ijtihad, berusaha kembali kepada Al-Quran dan Sunah, melarang taqlid, menghidupkan kembali pemikiran Islam. Dalam praktiknya di Indonesia, Muhammadiyah sangat bersemangat dalam membebaskan berbagai praktik ibadah Islam dari tindakan yang dianggap takhayul, bid'ah, dan khurafat. Sementara itu, praktik-praktik yang diamalkan pengikut NU justru banyak yang menurut Muhammadiyah dikategorikan dalam tindakan takhayul, bid'ah, dan khurafat, bahkan yang dianggap Sunah oleh NU. Misalnya Muhamadiyah melarang (bahkan membid'ahkan) bacaan qunut di waktu sholat Shubuh, sedangkan NU mensunahkannya. Berbagai tradisi yang berhubungan dengan siklus hidup manusia dari lahir, hidup hingga mati yang dikemas dalam nuansa Islami masih dilaksanakan di kalangan penganut NU, 
sehingga pengaruh NU memang sangat tampak di kalangan masyarakat pedesaan yang masih banyak melaksanakan tradisi.

Pada masyarakat desa dengan pemahaman ilmu agama yang sederhana, perbedaanperbedaan kecil dalam praktik-praktik keagamaan seperti itu sangat mudah memicu terjadinya konflik. Seperti yang pernah terjadi di Masjid Nurul Huda di Dusun Jetis sekitar 1976, dalam ibadah shalat tarawih yang dipimpin seorang imam dari Dusun Pagerjurang bernama Ahmat. Pada saat itu shalat tarawih dilaksanakan sebanyak 11 raka'at, namun jamaah menghendaki 23 raka'at. Hal itu kemudian memicu perdebatan sengit dan akhirnya jamaah masjid tidak bersedia dipimpin oleh Ahmat.

Lebih dari itu bahkan Dusun Pagerjurang, oleh warga dusun lain di Desa Pagersari dicap sebagai dusun orang Muhamadiyah dan dikenal dengan sebutan kamandiyah. ${ }^{4}$ Dalam banyak hal pada masyarakat dusun luar Pagerjurang telah terbentuk asumsi bahwa orang kamandiyah dinilai sebagai pengikut ekstrim. Pandangan ekstrim terhadap masyakarat Dusun Pagerjurang ini sangat terasa dalam kehidupan sehari-hari terutama pada saat diselenggarakan acara-acara penting di masyarakat. Misalnya pada bulan Sya'ban sebelum bulan puasa, beberapa dusun di Pagersari seperti Jetis, Tapen, Pongangan, Kamal, Tanggulangin, dan Karanggawang secara bergantian melaksanakan tradisi ruwahan/ nyadran, yaitu tradisi mengirim doa untuk para leluhur dan bersih makam yang dilaksanakan bersama-sama warga dusun dan diakhiri dengan selamatan bersama warga satu dusun dengan mengundang warga dusun lain. Masyarakat Dusun Pagerjurang tidak pernah melaksanakan tradisi itu, sehingga warganya juga tidak pernah diundang oleh warga dusun-dusun lain. Bahkan pada hari raya Idulfitri, jarang ada warga Dusun Jetis atau Tapen yang mau bersilaturahmi ke Pagerjurang, terlebih kamandiyah lebarannya tidak sama (Wawancara dengan H. Riyadi, 20 November 2011).

Bentuk konflik lain antara pengikut NU dan Muhammadiah adalah perbedaan pendapat terkait letak atau posisi masjid di Dusun Tapen yang ingin dibangun. Pembangunan masjid di dusun Tapen terjadi pada 1976. Bermula dari tanah wakaf yang diberikan oleh keluarga Den Dar. Keluarga Den Dar dikenal sebagai pengikut dan pengurus cabang organisasi Muhamadiyah yang sangat aktif. Sementara itu, perangkat dusun setempat bernama Dimyati kebetulan seorang Nahdhiyin (pengikut NU). Ada perbedaan pendapat dalam konsep letak dan bentuk bangunan masjid (Wawancara dengan Duiman, 21 November 2011). Karena perbedaan tersebut, proses pembangunan masjid sempat berjalan hampir terhenti. Peristiwa serupa terulang kembali pada 1985, ketika dua warga Pagersari bernama Yono dan Bejo yang merupakan pengikut Muhammadiyah ingin memperbaiki Masjid Tapen, namun takmir masjid setempat yang merupakan pengikut fanatik NU pada saat itu tidak mengizinkannya (Wawancara H. Wardono, 20 November 2011 dan Duiman, 21 November 2011).

\section{Konflik Keluarga}

Di Desa Pagersari terdapat keluarga-keluarga yang berasal dari golongan bendara dan priyayi yang sangat disegani masyarakat. Namun sering kali dalam keluarga-keluarga tersebut terjadi konflik internal yang dilatarbelakangi oleh permasalahan pembagian harta warisan. Seperti yang terjadi di Dusun Jetis pada kerabat keluarga besar Mbah Madun dan di Dusun Kamal pada keluarga besar Den Mas Ranudimejo. Permasalahan di antara dua kelompok kerabat tersebut sama-sama dilatarbelakangi masalah pembagian harta warisan yang tidak tuntas. Dalam keluaga $M b a h$ Madun, konflik terjadi di antara enam orang anaknya setelah $M b a h$ Madun meninggal. Meskipun ada permasalahan yang terjadi di antara keturunan $M b a h$ Madun, namun keluarga tersebut tetap disegani di masyarakat. Di antara keturunan $M b a h$ Madun, beberapa di antaranya adalah tokoh-tokoh di Desa Pagersari. Seperti Amat Danuri yang merupakan kepala Dusun Jetis sendiri, Sugito seorang guru/kepala sekolah dasar dan dalam struktur pemerintahan Desa Pagersari ia menjabat sebagai ketua Lembaga Ketahanan Masyarakat Desa (LKMD) di bawah pimpinan Wardono (Wawancara dengan H. Sugito, 15 Oktober 2011 dan S, 26 Desember 2011). 
Sementara itu, konflik pembagian harta warisan dalam keluarga Den Mas Ranudimejo di Dusun Kamal terjadi di antara saudara sepupu. Dengan demikian, konflik tersebut pada dasarnya bersumber dari masalah pembagian harta warisan generasi sebelumnya yang belum tuntas. Permasalahan itu menurun sampai pada generasi berikutnya. Perseteruan dalam keluarga tersebut bahkan sampai ke meja pengadilan.

Konflik keluarga yang berbeda terjadi pula di Dusun Karanggawang, yaitu antara dua orang saudara sepupu, yaitu Waliyun dengan Kromodiarjo. Sumber yang memicu konflik adalah permasalahan letak bangunan masjid yang ingin dibangun. Ketika dusun itu akan membangun masjid di atas tanah wakaf dari Waliyun dan Muhtarom pada 1985, Kromodiarjo menghendaki masjid dibangun di tepi jalan agar lebih mudah diakses oleh masyarakat umum. Akan tetapi, Waliyun sebagai pemberi tanah wakaf menghendaki agar letak bangunan masjid berdekatan dengan rumahnya.

\section{ELITE DAN UPAYA INTEGRASI SOSIAL DESA PAGERSARI}

\section{Keteladanan dan Kepemimpinan Elite Desa}

Wardono di mata para perangkat desa yang menjadi bawahannya adalah seorang pemimpin yang bisa menjadi teladan bagi masyarakat. Prinsip Jawa Ing Ngarso Sung Tuladha Ing Madya Mangun Karsa Tut Wuri Handayani (di depan memberi contoh, di tengah memberi semangat dan di belakang memberi daya kekuatan) rupanya menjadi prinsip dalam memimpin para perangkat desa dan masyarakat Desa Pagersari pada umumnya. Seperti yang diungkapkan oleh Sukisyanto, seorang sekretaris desa masa kepemimpinan Wardono, ia merasa mendapatkan pimpinan yang bisa mengayomi dan selalu memberi teladan yang baik bagi perangkat desa yang lain (Wawancara dengan Sukisyanto, 25 Desember 2011). Di desa ini, pada masa itu umumnya warga menyukai kepemimpinan Wardono. Dengan pembawaan yang ramah, murah senyum dan baik hati, ia berhasil menciptakan banyak kemajuan dalam hal pembangunan Desa Pagersari. Sebagai contoh, sebelum dipimpin Wardono, Dusun Jetis yang dikenal sebagai dusun bagi para mantan pengikut PKI belum memiliki masjid. Ketika pada 1975 ada bantuan dana untuk pembangunan sarana ibadah yang akan diberikan oleh perusahaan kertas Negara, PN. Blabak untuk desa-desa di sekitar pabrik perusahaan tersebut. Wardono segera mengusulkan agar masjid tersebut dibangun di Dusun Jetis. Wardono segera mengzinkan sebagian tanah bengkok di Dusun Jetis untuk dijadikan tempat pembangunan masjid (Wawancara dengan H. Sugito, 20 November 2011). Selain pembangunan masjid, pengerasan jalan yang menghubungkan dusun satu dengan yang lain juga dibangun di masa pemerintahan Wardono. Selain itu, yang paling menunjol adalah sarana penerangan listrik di Desa Pagersari mulai dibangun pada masa pemerintahan Wardono (Wawancara dengan Muh. Irsad, 25 November 2011). Seorang warga Dusun Kamal, Murniyati menyatakan bahwa Wardono adalah seorang yang baik, sederhana dan bisa menyikapi perbedaan agama yang ada di masyarakat dengan sikap ngemong, sehingga semua pihak mendapat perhatian, meskipun di masyarakat desa itu masalah agama sangat sensitif (Wawancara dengan Murniyati, 25 November 2011).

"Hal yang paling berkesan dari Wardono adalah selalu mengumpulkan masyarakat untuk bermusyawarah apabila ada program pembangunan seperti membangun masjid, pengerasan jalan, bahkan yang berhubungan dengan kegiatan ibu-ibu sekalipun, mau bermusyawarah" (Wawancara dengan Murniyati, 25 November 2011).

Sebagai seorang kepala desa, sudah menjadi tugas Wardono untuk menciptakan kehidupan masyarakat dengan suasana yang tertib dan aman. Oleh karena itu, berkaitan dengan berbagai konflik yang terjadi di Desa Pagersari, sebagai seorang kepala desa, Wardono selalu berupaya untuk membantu untuk mencarikan solusi dalam penyelesaian permasalahan-permasalahan tersebut. Wardono dalam menyikapi konflik antarkelompok 
pengikut NU dan Muhammadiyah misalnya, selalu menganjurkan warganya untuk senantiasa menjaga hubungan baik dan tetap saling menghargai keyakinan masing-masing. Dalam hal tersebut, Wardono tidak hanya sekedar memberi nasihat, tetapi juga berusaha memberikan keteladanan. Wardono dalam berbagai acara dusun termasuk nyadran misalnya, selalu menyempatkan diri untuk hadir. Sebagaimana diketahui Wardono dikenal sebagai seorang yang berasal dari Dusun Pagerjurang yang identik dengan sebutan kamandiyah. Namun dengan tindakan tersebut, ia berusaha untuk bersikap netral dan berusaha mendorong agar hubungan baik antarwarga Desa Pagersari dapat terjalin.

Terkait konflik perbedaan pendapat tentang konsep dan bentuk masjid antara pengikut NU dan Muhammadiyah, Wardono berusaha turun tangan dengan melakukan pendekatan-pendekatan pada kedua belah pihak dan meminta masukan dari masyarakat Dusun Tapen, tempat masjid tersebut akan didirikan. Pada akhirnya pembangunan masjid bisa berlangsung dan kokoh berdiri. Wardono dalam hal tersebut dituntut menjadi penengah atau mediator untuk mendamaikan pihak-pihak yang berkonflik (Wawancara dengan $\mathrm{H}$. Wardono, 21 November 2011). Termasuk pula di antaranya dalam konflik berkisar perebutan warisan keluarga yang terjadi di Dusun Jetis di antara keturunan Mbah Madun dan di Dusun Kamal di antara keluarga besar Den Mas Ranudimejo, Wardono sebagai kepala desa selalu mengambil peran sebagai penengah untuk menyelesaikan permasalahan tersebut. Bahkan pada konflik perebutan warisan pada keluarga Den Mas Ranudimejo yang kasusnya samapai ke pengadilan, Wardono selaku kepala desa turut berperan sebagai saksi untuk memberikan kesaksian administratif, yaitu berupa bukti-bukti administratif yang menunjukkan identitas harta berupa tanah yang dipersengketakan. Pada dasarnya dalam penyelesaian berbagai permasalahan yang terjadi antarmasyarakat Desa Pagersari, Wardono selalu mendahulukan jalan musyawarah dan perundingan. Biasanya Wardono berusaha mencari jalan tengah dengan memelajari permasalahan, kemudian mendengar suara dari masing-masing pihak yang berselisih secara terpisah dan juga mendengar suara masyarakat setempat. Setelah banyak mendapatkan informasi, Wardono kemudian memanggil dua pihak yang berselisih kembali untuk diajak musyawarah hingga pihak-pihak yang berkonflik menemukan titik tengah atau jalan penyelesaian yang disepakati bersama (Wawancara dengan H. Wardono, 29 Juni 2011 dan H. Riyadi, 29 Juni 2011). Jalan musyawarah di antaranya digunakan untuk menyelesakan permasalahan konflik antara saudara sepupu Waliyun dengan Kromodiarjo di Dusun Karanggawang terkait letak masjid yang akan dibangun. Masjid di Dusun Karanggawang pada akhirnya dibangun di dekat rumah Waliyun (Wawancara dengan Maksum pada 26 Desember 2011, 31 Desember 2011). Oleh karena itu, penyelesaian-penyelesaian konflik melalui jalur hukum biasanya diambil jika penyelesaian atas konflik tersebut sudah mengalami kebuntuan (Wawancara dengan $\mathrm{H}$. Wardono, 20 November 2011).

\section{Upaya Konsolidasi Masyarakat Pagersari}

Pemerintahan Desa Pagersari di bawah kepemimpinan Wardono dihadapkan pada permasalahan kompleks. Ia sangat memahami bahwa masyarakat yang berada di bawah kepimpinannya adalah masyarakat yang memiliki potensi konflik satu sama lain. Sebagaimana diketahui, sebagian kecil dari masyarakat Desa Pagersari merupakan mantan pengikut PKI, sebagian besar yang lain merupakan kelompok masyarakat Islam NU dan Muhammadiyah. Melihat kondisi tersebut, ia merasa harus melakukan konsolidasi warganya, sehingga dapat tercipta kehidupan masyarakat yang rukun dan sejahtera. Bagaimana menghadapi mantan pengikut organisasi terlarang PKI yang sudah dibebaskan dan kembali ke Desa Pagersari menjadi salah satu permasalahan kepemimpinan Wardono. Mereka secara tersirat memendam kebencian dan ketidakrelaan karena mendapat perlakuan diskriminatif. Hal tersebut menjadi salah satu potensi konflik yang besar di Desa Pagersari. Perlakuan diskriminatif yang paling dirasakan 
oleh warga yang mendapat sebutan eks-PKI itu adalah pemberian tanda Eks-Tapol (ET) atau Organisasi Terlarang (OT) pada Kartu Tanda Penduduk (KTP). Berdasar data yang diperoleh, tercatat sebanyak 51 orang warga Desa Pagersari merupakan mantan pengikut organisasi terlarang PKI (Arsip Kantor Desa Pagersari, Salinan Daftar Nama OT G30S PKI Desa Pagersari). Mereka umumnya berasal dari Dusun Jetis. Beberapa dari mereka yang mendapat tanda OT pada KTP, merespon hal tersebut dengan berusaha memalsukan identitas anak-anak mereka sebagai anak dari adik atau kakak atau kerabat mereka yang lain, yang bersih dari sebutan eks PKI. Hal itu dilakukan demi menyelamatkan masa depan anak-anak tersebut. Seperti yang dilakukan oleh seorang warga Desa Pagersari berinisal S. Pada data administrasi di sekolah ketiga anaknya, tertera nama orang tua yang berbeda-beda (Wawancara dengan S, 26 Desember 2011).

Setelah memasuki masa Orde Baru, orangorang eks-PKI sangat sulit berbaur dengan kelompok masyarakat yang lain. Berbagai larangan diberlakukan bagi kelompok mantan pengikut PKI, misalnya mereka tidak diperbolehkan terlibat dalam kegiatan-kegiatan desa, tidak boleh mengikuti kegiatan organisasi baik organisasi pemerintah maupun nonpemerintah, juga tidak boleh menduduki jabatan-jabatan baik formal maupun nonformal di masyarakat. Hal itu membuat ruang gerak mereka menjadi terbatas dan banyak di antara mereka yang merasa terpinggirkan dari kehidupan masayarakat pada umumnya. Oleh karena itu, Wardono memahami bahwa mereka adalah orang-orang yang kagol (kecewa), sehingga ia merasa harus menghadapi mereka dengan bombongan (dibesarkan hatinya) agar orang-orang tersebut merasa masih dihargai dan mendapat tempat di masyarakat (Wawancara dengan H. Wardono, 20 November 2011). Terhadap beberapa orang eks-PKI yang dipandang bisa diajak berkomunikasi dengan baik, Wardono sering kali mengajak mereka berbicang jika bertemu. Namun, Wardono menghindari berkunjung secara langsung ke rumah-rumah mereka, karena ia merasa sebagai wakil pemerintahan di desa ia harus tetap menjaga jarak untuk menjaga kredibilitasnya dari pengaruh PKI. Oleh karena itu, pembauran sepenuhnya tidak akan bisa dilakukan karena berbagai larangan yang diberlakukan. Namun demikian, Wardono tetap berusaha merangkul dan menciptakan hubungan baik dengan semua kelompok masyarakat di desa tersebut, termasuk kelompok mantan pengikut PKI. Seperti yang pernah dilakukan terhadap salah seorang mantan pengikut PKI berinisial $T$, seorang pengrajin tahu dari Dusun Jetis yang sering kali bertemu diajak diskusi oleh Wardono seputar usahanya dan bagaimana mengembangkan produksi dan pemasarannya (Wawancara dengan $\mathrm{T}, 26$ Desember 2011). Demikian pula dengan seorang warga Pongangan berinisial K, seorang mantan guru sekolah dasar yang diberhentikan karena dituduh terlibat dalam keanggotaan PKI yang kemudian menjadi tukang cukur. Wardono menjadi pelanggan setia pada usaha cukur milik K. Melalui K terutama ia mengetahui bagaimana harapan warga mantan pengikut PKI terhadap jalannya pemerintahan desa dan kehidupan masyarakat di Desa Pagersari. Menurut Wardono, orang-orang tersebut memiliki ikatan yang erat satu sama lain, karena merasa sebagai satu kelompok (Wawancara dengan $\mathrm{H}$. Wardono, 20 November 2011).

\section{Proses Integrasi Sosial melalui Pendekatan Agama dan Budaya}

Berbagai kegiatan keagamaan dan kebudayaan menjadi sarana-sarana handal untuk melakukan pendekatan-pendekatan kepada kelompokkelompok masyarakat yang terlibat dalam berbagai konflik. Salah satu masalah yang menjadi pemicu konflik dalam kehidupan sosial di Pagersari adalah perbedaan paham agama. Oleh karena itu, melalui agama pula Wardono berusaha mempersatukan masyarakatnya. Wardono di lingkungan tempat tinggalnya dikenal sebagai pengikut organisasi Muhammadiyah. Namun demikian, sebagai seorang kepala desa ia tidak ingin menonjolkan hal tersebut, karena ingin memosisikan diri pada pihak yang netral. Ia dalam hal tersebut pernah menyelenggarakan tahlilan untuk almarhum ibunya yang meninggal pada 1970-an. Meskipun 
tindakannya mendapat reaksi yang beragam dari berbagai pihak, Wardono ingin menunjukkan pada masyarakat Pagersari bahwa dirinya adalah penganut Islam yang tidak berpihak pada paham tertentu, baik itu Muhammadiyah maupun NU. Selain itu, pada ibadah shalat Jumat, Wardono secara bergantian melaksanakan ibadah dari dusun ke dusun, begitu juga pada ibadah yang dilakukan pada bulan puasa, secara bergantian melakukan shalat tarawih di masjid Muhammadiyah yang berada di depan rumahnya dan di langgar kulon di dusun yang sama, tempat para pengikut NU biasa melakukan shalat tarawih (Wawancara dengan H. Riyadi, 29 Juni 2011).

Sebagai bentuk upaya mempersatukan masyarakat dalam pandangan keagamaan (Islam khususnya), Wardono mengirimkan guru-guru agama yang bisa diterima masyarakat. Seperti di Dusun Jetis yang mayoritas masyarakatnya dianggap orang Abangan, Wardono menempatkan dua orang guru agama bernama Amat dan Riyadi yang berasal dari Dusun Pagerjurang. Mereka sejak 1976 mengajar mengaji dan akidah Islam setiap sore di Dusun Jetis, meskipun tidak menerima gaji. Masyarakat Dusun Jetis dianggap lebih terbuka oleh Wardono dibandingkan masyarakat dusun lain. Berbeda dari masyarakat Dusun Tapen misalnya, yang dinilai lebih sensitif. Dusun Tapen dikenal sebagai basis pengikut NU, sehingga cenderung sulit diberi masukan-masukan, terutama dalam hal akidah Islam oleh warga Pagerjurang yang identik sebagai pengikut Muhammadiyah.

Dusun yang lain tidak luput dari perhatian Wardono dalam hal agama. Di Dusun Kamal, agama yang dianut masyarakat lebih beragam. Selain Islam, di dusun itu juga ada beberapa orang yang menganut agama Katholik dan Kristen. Permasalahan konflik yang berlatar belakang agama di dusun itu hampir tidak ada, terlebih karena paham Islam yang dianut warga setempat cenderung sama seperti Dusun Jetis, yaitu Abangan (Wawancara dengan Murniyati, 25 November 2011). Di dalam keragaman agama tersebut, masyarakat Kamal hidup rukun berdampingan, bahkan dapat bekerja sama satu sama lain.
Sebuah acara pengajian bersama antara masyarakat Dusun Tapen yang merupakan pengikut NU dan masyarakat Dusun Pagerjurang yang merupakan pengikut Muhammadiyah diinisiasi pada masa kepemimpinan Wardono. Pengajian tersebut dikenal dengan sebutan "Pengajian Selapanan" dan dilaksanakan di sekolah Madrasah Ibtida'iyah (MI) Muhammadiyah di Desa Pagersari setiap tiga puluh lima hari sekali. Kegiatan pengajian bersama itu mulai diselenggarakan sejak awal 1980-an. Sebagai Kepala Desa Pagersari, Wardono berusaha menjembatani perbedaan paham antara dua dusun tersebut. Ia juga menunjuk tokoh-tokoh masyarakat kedua dusun untuk mengurus secara bersama-sama kegiatan pengajian bersama itu. Mereka antara lain Muhadi dan Duiman yang merupakan tokoh NU dari Dusun Tapen, serta Ansor dan Sukisyanto yang merupakan tokoh Muhammadiyah dari Dusun Pagerjurang. Namun, upaya integrasi melalui acara "Pengajian Selapanan" itu dalam perkembangannya tidak berjalan dengan mulus. Beberapa warga Dusun Tapen menginginkan agar acara tersebut tidak dilaksanakan di sekolah MI Muhamadiyah, karena tempat tersebut dianggap identik dengan Muhammadiyah. Oleh karena itu, Duiman dan Muhadi kemudian mengusulkan untuk memindahkan tempat penyelenggaraan acara di tempat yang lebih umum, yaitu di Balai Desa Pagersari. Akan tetapi, pelaksanaan pengajian di balai desa kemudian diprotes warga lain, karena tempat itu dianggap tempat umum yang seharusnya hanya digunakan untuk kepentingan umum yang berhubungan dengan kegiatan desa, bukan untuk kegiatan keagamaan tertentu. Perbedaan pendapat itu berhasil diselesaikan dengan damai hingga semua pihak menyadari bahwa masyarakat Islam butuh persatuan karena dengan bersatu akan lebih memperkuat image bahwa Islam itu adalah agama yang damai (Wawancara dengan $\mathrm{H}$. Wardono, 20 November 2011 dan Duiman, 25 November 2011). Pada akhirnya dicapai kesepakatan bahwa acara "Pengajian Selapanan" tetap dilaksanakan di gedung sekolah MI Muhammadiyah dan dilaksanakan setiap Minggu Kliwon (selapan). 
Upaya integrasi masyarakat Pagersari juga dilakukan melalui kelompok-kelompok kesenian dan berbagai acara lokal. Masyarakat Desa Pagersari dalam kehidupan sosial budaya memiliki dua kelompok kesenian tradisonal. Dua kelompok kesenian tersebut adalah kelompok kesenian jathilan (Jaran Kepang) bernama "Margo Utomo" yang berada di Dusun Jetis dan kelompok kesenian "Kobrasiswa" di Dusun Tapen. Kesenian jathilan cenderung bernuansa magis, sehingga dianggap sebagai kesenian kelompok Abangan di Desa Pagersari. Sementara itu, kesenian Kobrasiswa bernuansa Islami dengan syair-syair bernuansa Islam sebagai pengiring gerakan tarian yang dimainkan.

Kesenian jathilan yang dibawakan oleh kelompok kesenian Margo Utomo adalah sebuah jenis kesenian yang dimainkan dengan properti berupa kuda tiruan yang terbuat dari anyaman bambu atau disebut kepang. Oleh karena itu, kesenian ini juga sering disebut jaran kepang. Kelompok ini berdiri sekitar 1970 dengan anggota terdiri dari para pemuda Dusun Jetis. Nama "Margo Utomo" sendiri berarti jalan menuju keutamaan/kebaikan (Wawancara dengan Slamet Bagong, 16 Oktober 2011). Pemberian nama tersebut pada dasarnya sarat dengan harapan bahwa melalui pembentukan kelompok kesenian jatilan tersebut, para pemuda di Dusun Jetis dapat bersama-sama berkumpul untuk mencari jalan kebaikan. ${ }^{5}$

Kelompok kesenian lain yang berkembang di Desa Pagersari adalah kelompok Kobrasiswa di Dusun Tapen. Kobrasiswa dalam pertunjukan kesenian yang dibawakan selalu melibatkan banyak orang. Jika jathilan bernuansa magis, maka pertunjukan kesenian Kobrasiswa bernuansa Islam. Hal itu terlihat dari lagu-lagu yang digunakan sebagai pengiring tarian, sangat khas bernuansa Islam. Seperti cuplikan syair berikut: Ayo simbah simbah mbah, nuli dha ngibadah, umure ra tambah mundhak kakean polah... (Ayo kakek kek, segera beribadah, umurnya tidak bertambah justru kebanyakan tingkah..). Syair tersebut menjadi nyanyian pembuka. Dengan pakaian bernuansa Timur Tengah dan gerakan tari yang sangat dinamis dengan diiringi suara musik yang keras dan syair- syair Islami yang mengajak orang untuk selalu menyembah kepada Allah. Pertunjukkan Kobrasiswa biasanya dimainkan pada malam hari. Untuk memainkan kesenian ini membutuhkan sekitar 30 orang, sehingga membutuhkan kerja sama yang kompak di antara para pemain dan pengurus.

Kedua kelompok kesenian yang berasal dari Desa Pagersari ini digunakan oleh Wardono sebagai sarana mengakrabkan masyarakat satu sama lain. Untuk itu ia sebagai kepala desa berusaha selalu mendukung segala bentuk kegiatan kelompok-kelompok kesenian itu. Dalam hal itu Wardono misalnya aktif mempromosikan kelompok-kelompok tersebut baik di lingkungan Desa Pagersari maupun di lingkungan sekitarnya. Selain itu, pada masa kepemimpinan Wardono, bantuan dana dan dukungan moral didapatkan oleh kelompokkelompok kesenian tersebut. Pada setiap pementasan baik di desa sendiri maupun di luar desa, Wardono selalu menyempatkan diri untuk ikut mendampingi, sehingga pengurus dan anggota kesenian merasa mendapat dukungan penuh dari pemerintah desa (Wawancara dengan Duiman, 21 November 2011). Kedua kelompok kesenian tersebut cukup terkenal dan sering kali diundang untuk mengisi berbagai acara lokal. Kelompok Margo Utomo misalnya, sering diundang untuk melakukan pementasan pada perayaan Hari Ulang Tahun Kemerdekaan Republik Indonesia 17 Agustus di halaman Kantor Kecamatan atau di halaman Kantor Kabupaten atas undangan pemerintah daerah setempat. Selain itu, kedua kelompok kesenian tersebut juga sering kali diminta melakukan pementasan pada hajat-hajat besar di masyarakat, seperti pada acara-acara pernikahan atau sunatan dan bahkan setiap hari raya Idulfitri sudah menjadi tradisi untuk selalu pentas.

Terkait dengan integrasi masyarakat Pagersari, Wardono menyatakan bahwa di satu sisi kegiatan kelompok-kelompok kesenian tersebut menjadi sarana hiburan, dan di sisi lain menjadi sarana pemersatu masyarakat setempat. Lebih lanjut Wardono misalnya menyatakan bahwa, "Lha wong ana sing jothakan wae terus dadi akur meneh gara-gara main kobrasiswa" (ada orang yang sedang tidak bertegur sapa saja 
menjadi akur damai kembali karena bermain di Kobrasiswa). Terlebih lagi, ketika berbagai kegiatan kesenian yang dipentaskan oleh kedua kelompok tersebut di Desa Pagersari, maka banyak orang akan berkumpul untuk menonton, dan suasana itu mendorong terciptanya kedekatan antarwarga satu sama lain.

\section{SIMPULAN}

Konflik sosial di Desa Pagersari bersumber pada permasalahan perbedaan paham politik, perbedaan paham keagamaan, dan permasalahan internal keluarga-keluarga terhormat di wilayah desa itu. Guna menyelesaikan permasalahan tersebut dan mempertahankan integrasi masyarakat Desa Pagersari, tokoh masyarakat seperti elite lokal dalam hal itu memiliki peran penting di dalamnya. Desa Pagersari di bawah kepemimpinan Wardono berusaha melakukan konsolidasi seluruh warganya guna mempertahankan keutuhan bersama. Integrasi sosial masyarakat Desa Pagersari dilakukan melalui beberapa pendekatan, antara lain melalui pemberian keteladanan dan kepemimpinan yang baik, melalui pendekatan agama dan budaya. Integrasi sosial melalui pemberian keteladanan dan kepemimpinan yang baik terhadap masyarakat diberikan oleh kepala desa sebagai elite lokal. Sementara itu, pendekatan agama terutama dilakukan melalui acara-acara bernuansa keagamaan seperti pengajian bersama antarwarga yang berkonflik. Sementara itu, integrasi sosial melalui pendekatan budaya dilakukan melalui kelompok-kelompok kesenian lokal dan acara-acara bernuansa budaya yang dihadiri bersama oleh masyarakat lokal, melalui berbagai pendekatan tersebut.

\section{CATATAN}

${ }^{1}$ Muhammadiyah lahir 1914, didirikan oleh KH. Ahmad Dahlan adalah organisasi yang lahir dari inspirasi pemikir-pemikir moderen seperti Jamaluddin Al-Afghani, Muhammad Abduh, Rasyid Rida (yang sangat rasional) sekaligus pemikir salaf (yang literalis) seperti Ibn Taymiah, Muhammad bin Abdul Wahab.

${ }^{2}$ Koentjaraningrat menguraikan bahwa para penganut Islam yang pertama pada umumnya takwa dan patuh menjalankan shalat lima kali sehari. Secara teratur mereka pergi ke masjid setiap hari Jumat siang, tertib menjalankan puasa setiap bulan Ramadhan, patuh menyumbangkan zakat fitrah pada waktu-waktu yang telah diharuskan oleh syariah, dan bercita-cita menjalankan kewajiban naik haji jika mereka mampu, serta pantang makan daging babi. Di kalangan orang Jawa mereka sering disebut orang "santri". Adapun penganut Islam yang kedua tidak pernah menjalankan kewajiban-kewajiban tersebut, tetapi mempunyai konsep lain tentang agama dan melaksanakan upacara-upacara keagamaan lain, oleh orang Jawa disebut agama "Islam Jawa" atau Kejawen. Sementara pengikutnya disebut orang “Abangan” (Koentjaraningrat, 1982: 355-356). Ajaran yang dianut orang Abangan pada dasarnya merupakan sinkretisme ajaran Islam dengan praktikpraktik kepercayaan dinamisme-animisme, ajaran agama Hindu dan Buddha.

${ }^{3}$ Sebagian besar narasumber adalah warga Pagersari yang secara langsung maupun tidak langsung menjadi saksi sejarah berlangsungnya proses integrasi sosial ${ }^{4}$ Istilah kamandiyah merupakan sebutan untuk para penganut paham Muhammadiyah yang oleh masyarakat penganut paham NU dianggap ekstrim terutama karena tidak mengadaptasi terhadap berbagai tradisi yang sudah berkembang di masyarakat.

${ }^{5}$ Kelompok kesenian Margo Utomo dikelola secara kekeluargaan. Tidak pernah dibentuk kepengurusan secara formal, tetapi hanya berdasar kesepakatan dan disebut sebagai pengurus "abadi", karena tidak ada batasan sampai kapan masa kepengurusan tersebut berakhir (Wawancara dengan Sudaryono, 16 Oktober 2011). Kepengurusan Margo Utomo terdiri dari Slamet Bagong sebagai Ketua, Basari sebagai wakil, Suradi sebagai sekretaris dan Sungkono sebagai bendahara, serta yang bertindak sebagai pawang roh semula dipegang oleh seorang sesepuh bernama Mbah Ali hingga 2005 dan digantikan oleh Subronto (Wawancara dengan Sudaryono, 16 Oktober 2011).

\section{REFERENSI}

Arsip Pribadi Koleksi Wardono, Pemberhentian Tugas Beladjar.

Arsip Pribadi Koleksi Wardono, Pengabsjahan Pemilihan Kepala Desa Pagersari jang Diadakan pada Tanggal 8 Pebruari 1967.

Arsip Daerah Kabupaten Magelang, Petikan Keputusan Bupati Kepala Daerah Tingkat II Magelang Nomor: 188.4/207/Kep/ 
Pem/1988 Tentang Pemberhentian dengan Hormat $H$. Wardono dari Jabatannya sebagai kepala Desa Pagersari Kecamatan Mungkid Kabupaten Magelang.

Arsip Pribadi Koleksi Wardono, Berita Atjara Penjumpahan.

Arsip Desa Pagersari, Salinan Daftar Nama OT G 30 S PKI Desa Pagersari Daftar Lampiran. Arsip Daerah Kabupaten Magelang.

Arsip Daerah Kabupaten Magelang, Surat Keputusan Bupati Kepala Daerah Kabupaten Magelang, tanggal 15 Maret Nomer 15/Dsa.B/S.K/1967 Tentang Pologoro.

Arsip Daerah Kabupaten Magelang, Daftar Lampiran Surat Keputusan Bupati Kepala Daerah Kabupaten Magelang, tanggal 15 Maret Nomer 15/Dsa.B/S.K/1967 tentang Pologoro.

Burke, P. (1992). History and Social Theory. Cambridge: Polity Press.

Gottschalk, L. (1983). Mengerti Sejarah terjemahan Nugroho Notosusanto. Jakarta: Universitas Indonesia.

Karim, M. R. (1983). Perjalanan Partai Politik di Indonesia: Sebuah Potret Pasang Surut. Jakarta: Rajawali.

Keller, S. (1995). Penguasa dan Kelompok Elite, Peranan Elite Penentu dalam Masyarakat Modern. Jakarta: PT. Raja Grafindo Persada.

Koentjaraningrat (2002). Manusia dan Kebudayaan di Indonesia. Jakarta: Djambatan.

Ma'arif, Ahmad Syafii (1985). Studi Tentang Percaturan dalam Konstituante: Islam dan Masalah Kenegaraan. Jakarta: LP3ES.

Maran, R. R. (2001). Pengantar Sosiologi Politik. Jakarta: Rineka Cipta.

Poerwaderminta, W.L.T. (2000). Kamus Besar Bahasa Indonesia. Yogyakarta: PT. Lingkar Pena.

Wijono, S. (1993). Konflik Dalam Organisasi/ industri Dengan Strategi Pendekatan Psikologis Semarang: Satya Wacana.

\section{DAFTAR INFORMAN}

Wawancara dengan Duiman (64 tahun), mantan Bendahara Kelompok Kesenian Kobrasiswa Dusun Tapen.

Wawancara dengan H. Wardono (70 tahun), mantan kepala Desa Pagersari.

Wawancara dengan H. Sugito (72 tahun), pensiunan Penilik TK/SD, mantan Ketua LKMD.

Wawancara dengan Hj. Mami Sukami (72 tahun), Pensiunan Kepala SDN Pagersari.

Wawancara dengan H. Riyadi (60 tahun), tokoh agama, warga Dusun Pagerjurang.

Wawancara dengan H. Sukisyanto (65 tahun) mantan Sekretaris Desa Pagersari, warga Dusun Pagerjurang.

Wawancara dengan Muhadi (71 tahun), petani, warga Dusun Jetis.

Wawancara dengan Muhaimin (65 tahun), mantan Ketua Kelompok Kesenian Dusun Tapen.

Wawancara dengan Sugati (70 tahun), petani, warga Dusun Jetis.

Wawancara dengan Muh. Irsad (60 tahun), warga Dusun Tanggulangin.

Wawancara dengan Murniyati (55 tahun), warga Dusun Kamal.

Wawancara dengan S (70 tahun), mantan pengikut PKI, warga Dusun Jetis.

Wawancara dengan Slamet Bagong (55 tahun), Ketua Kesenian Jatilan Margo Utomo.

Wawancara dengan Sudaryono (35 tahun), Kepala Dusun Jetis.

Wawancara dengan Sunyoto (69 tahun), mantan Ketua Urusan Kesejahteraan Desa Pagersari. 